\title{
Is the Phone Mightier Than the Sword? Cellphones and Insurgent Violence in Iraq
}

\author{
Jacob N. Shapiro and Nils B. Weidmann
}

\begin{abstract}
Does improved communication provided by modern cellphone technology affect the rise or fall of violence during insurgencies? A priori predictions are ambiguous; introducing cellphones can enhance insurgent communications but can also make it easier for the population to share information with counterinsurgents and creates opportunities for signals intelligence collection. We provide the first systematic micro-level test of the effect of cellphone communication on conflict using data on Iraq's cellphone network (2004-2009) and event data on violence. We show that increased mobile communications reduced insurgent violence in Iraq, both at the district level and for specific local coverage areas. The results provide support for models of insurgency that focus on noncombatants providing information as the key constraint on violent groups and highlight the fact that small changes in the transaction costs of cooperating with the government can have large macro effects on conflict.
\end{abstract}

In 2007, cellphone subscriptions reached 3.3 billion worldwide, which corresponds to half of the world's population. ${ }^{1}$ The increase in wireless communication has been one of the most important technological advances of the past two decades. There are plenty of reasons to be enthusiastic about this progress. For example, economists have shown that improved mobile communications can enhance market performance in Indian fishing communities and reduce price dispersion in grain markets in Niger. ${ }^{2}$ At the same time, however, there are circumstances under which cellphone communication can have more pernicious effects. Governments are increasingly afraid

The authors thank Zain Iraq for generously sharing data on their cellphone towers. Patson Anius, Walid Jallo, Alberto Lopez, Tijjay Majiyagbe, Lewis Shade, and Frederic Wohl provided critical insights into the construction of the Iraqi cellphone network. Our anonymous reviewers, the $I O$ editorial team, and seminar participants at Colombia, Georgetown, Harvard, the Harris School, Michigan, Pennsylvania, Princeton, and Stanford Universities honed this article with their incisive comments. Our students and colleagues with operational experience in Afghanistan and Iraq provided valuable insights regarding mechanisms and many informative anecdotes. Josh Martin and Thomas Scherer provided fantastic research assistance throughout the project. Thanks to Josh Borkowski and Zeynep Bulutgil for conducting the coding of ethnic populations at the district level. This material is based on work supported by the Air Force Office of Scientific Research (AFOSR) under Award No. FA9550-09-1-0314, by the National Science Foundation (NSF) under Award No. CNS-0905086, by the Army Research Office (ARO) under Award No. W911NF-11-1-0036, and by the Alexander von Humboldt Foundation under a Sofja Kovalevskaja Award. Any opinions, findings, and conclusions or recommendations expressed in this publication are those of the author(s) and do not necessarily reflect the views of AFOSR, United States Department of Defense, NSF, or ARO.

1. Tamo Virki, "Global Cellphone Use at 50 percent," Reuters (Internet ed.), 29 November 2007.

2. See Jensen 2011; and Aker 2010. 
of the potential for collective mobilization that is introduced by modern communication technology. During the early 2011 protests in Egypt, for example, the Hosni Mubarak government shut down all cellphone communications in an attempt to stop the large crowd of protesters from growing. ${ }^{3}$ Analysts of organized crime, terrorism, and insurgency have long argued that the spread of cheap and reliable mobile communications will open up new organizational models for terrorists and rebels. ${ }^{4}$ Indeed, recent work shows that cross-nationally the correlation between the introduction of cellular coverage and conflict may be positive, at least in Africa. ${ }^{5}$

If cellphone communication is conducive to subversive action, insurgents should be among the keenest adopters of this technology. Anecdotal evidence from Iraq suggests this is the case, with press reports calling cellphones an "explosive tool for insurgents" 6 and some arguing that mobile communications enabled a "networked insurgency" in Iraq. ${ }^{7}$ That cellphones can be key infrastructure for insurgent communication is corroborated by the observation that although insurgents in Iraq frequently attacked water and electricity networks, they carefully spared the cellphone network, ${ }^{8}$ and even threatened telecommunication companies for not doing enough to maintain their network. ${ }^{9}$ This pattern from Iraq contrasts with anecdotes from Afghanistan during the same period, where the Taliban insurgents seemed afraid of cellphone technology. In an attempt to prevent villagers from calling in tips to the military forces, they issued decrees ordering all cellphone towers to be turned off at night and they attacked and destroyed cellphone towers for the same purpose. ${ }^{10}$

Theoretically it is not obvious whether or how the availability of cellular communications influences political violence. Cellphones make collective action easier; equipped with light, mobile communication devices, insurgents can easily coordinate actions, execute attacks, and quickly react to counterinsurgency operations. ${ }^{11}$ Following this line of reasoning, increased cellphone availability should lead to higher levels of violence. At the same time, however, cellphone availability could

3. Matt Richtel, "Egypt Cuts Off Most Internet and Cellphone Service," New York Times, 29 January 2011, A13.

4. See, for example, Arquilla, Ronfeldt, and Zanini 1999; and Andreas 2002.

5. Pierskalla and Hollenbach 2013.

6. "Cellphone Technology an Explosive Tool for Insurgents," Washington Times (Internet ed.), 7 March 2005.

7. Muckian 2006.

8. Jon Brand, "Iraqi Insurgents Target Water and Electricity, but Spare the Cellphone." PBS Newshour Extra, 29 January 2007.

9. Ryhs Blakely, "Terrorists ‘Threaten' Iraq Mobile Operators,” The Times (Internet ed.), 22 July 2005.

10. See Yaroslav Trofimov, "Cell Carriers Bow to Taliban Threat," Wall Street Journal (Internet ed.), 23 March 2010; and Noah Shachtman, "Taliban Threatens Cell Towers," Wired (Internet ed.), 25 February 2008. Unfortunately, we cannot identify the causal impact of cellphones on violence in Afghanistan because there is no source of plausibly exogenous variation in the timing of cell tower construction there. Shapiro has worked with the largest cellular provider in Afghanistan on research projects since early 2011 and it is clear that (1) violence and potential violence were major considerations for them throughout their build-out; and (2) they often had to turn towers on and off at the request of local Taliban commanders.

11. See, for example, Cordesman 2005; Leahy 2005; and Strother 2007. 
benefit counterinsurgents. In general, cellphones make it easier for the population to share information about insurgent activity, and to safely and anonymously call in tips. If this were true, and if the population's provision of information to counterinsurgents were generally the binding constraint on the production of violence, then greater cellphone availability would lead to less violence. ${ }^{12}$ On the other hand, insurgent use of cellphones may create operational vulnerabilities given many governments' limited ability to monitor them.

We make the first systematic micro-level attempt to examine whether cellular communications networks are security enhancing or not. Using detailed data on cellphone networks and violence in Iraq for 2004 to 2009, we estimate the effect of cellphone network expansion on insurgent violence at two levels. First, because the insurgency was organized regionally, we conduct a district-level analysis, assessing whether increased coverage at the district level is associated with changes in violence. We find that better coverage at the district level leads to a clear and robust decrease in insurgent attacks for most of the war. Second, to provide evidence on the mechanisms behind the main district-level effects, we study the local effect of cellphone towers within specific coverage areas. Using a spatial-temporal difference-in-difference design, we show that after a tower is turned on, there is a large drop in the number of improvised explosive device (IED) attacks in the area around towers that introduce substantial new coverage, but not around towers that merely increase existing capacity. This finding is especially striking as cellular coverage opens up a broad range of technologies for fusing IEDs. Importantly, these effects extend a bit beyond the immediate coverage area of new towers. Since insurgents in Iraq organized in units that covered areas larger than immediate coverage areas this pattern is consistent with our interpretation that the violence reduction engendered by turning on new coverage reflects an increased ability of counterinsurgents to act against militants.

These results should inform the theoretical literature on nonstate conflict in two ways. First, they highlight the centrality of civilian decision making over information provision in determining equilibrium levels of violence in civil conflicts. Specifically, our results show that in a conflict where rebels faced a militarily competent government (that is, Iraq and its US allies), exogenous reductions in the costs of communication (costs that should have increased the productivity of labor for rebels) led to reduced violence. This is powerful evidence for the theoretical approaches that focus on information sharing by civilians as the binding constraint on insurgent violence, and offers further evidence for the criticality of local information that numerous scholars have highlighted. ${ }^{13}$ Second, and more broadly, the results show that small changes in the transaction costs for communication can have dramatic effects

12. For a workhorse three-actor model in which information is the key constraint on insurgents, see Berman, Shapiro, and Felter 2011. For a two-actor model that considers both labor and information constraints on insurgency that has similar implications for what happens when the ability to share information safely increases, see Vanden Eynde 2011.

13. For a three-actor model in which insurgents make a strategic choice to limit violence in response to civilians' subsequent decisions about information sharing, see Berman, Shapiro, and Felter 2011. For 
on levels of violence. In our tower-level analysis the introduction of coverage decreases violence by about 40 percent from the mean level in areas that receive new coverage at some point. This is a considerable effect, especially given that constructing a cellular tower in Iraq was quite cheap, between $\$ 50,000$ and $\$ 200,000$ according to Zain Iraq - the nation's largest cellphone provider. This result has implications for theoretical models of civil conflict, but also important consequences for policy. While it is typically assumed that violence reduction is costly, we show that it need not be; relatively simple and inexpensive measures can be very effective under the right circumstances.

\section{Cellphones and Insurgent Violence}

Theories of insurgent violence and collective action provide conflicting predictions about the impact of introducing cellular communications into areas with ongoing violence. In the context of the recent uprising in the Arab world, modern communication - and in particular cellphone technology—is frequently mentioned as a key catalyst of rebellion because it facilitates collective action. The argument is that by making it possible for people to coordinate mass protest, these technologies play a key role in toppling autocratic regimes and paving the way for democracy. ${ }^{14}$ This thinking is rooted in the social movements literature, which has shown that efficient communication critically affects a movement's capability for organizational mobilization. ${ }^{15}$ In a different context, however, fast distribution of information between the members of a movement could also foster less favorable outcomes. During an insurgency, cellular communication technology could lead to increasing violence by making it easier for insurgents to coordinate attacks, mass forces, and by operating in a coordinated fashion without a defined chain of command.

The best evidence to date on the average impact of mobile communications on conflict across countries comes from studying the impact of introducing mobile communications on $55 \times 55 \mathrm{~km}$ grid cells in Africa. ${ }^{16}$ There the introduction of new cellular coverage is associated with a .5 to 1 percentage point increase in the probability of an armed conflict event being recorded in the Uppsala Conflict Data Program (UCDP) Georeferenced Event Dataset (UCDP GED) in the following year. ${ }^{17}$ From a theoretical perspective, many governments in Africa lack the means to exploit information provided about insurgents, and so the constraints to insurgent violence could 
be fundamentally different there, on average, than in settings where governments do have such capacity.

From an inferential perspective, the study highlights the empirical challenges in this area. Two issues are of concern. First, violent events are more likely to be recorded when people in an area are in regular contact with friends and relatives in other areas. This is why systems such as Ushahidi-a crowd-sourced reporting platform for events of various kinds-work for tracking violence in cities with rich cellular coverage, but it creates a correlation between measurement error and the key explanatory variable in the study. Second, the authors rely on violence data based to a large extent on media reports, where a violent event is geo-referenced using the place name mentioned in the report. However, news reports do not usually give precise geographic coordinates; rather, they mention the nearest major city. Without more detailed information, violent events will be referenced to these cities. These large population agglomerations are exactly where the cellphone network is primarily introduced. It is thus hard to know for certain if the positive correlation stems from the fact there seemingly is no violence where there are no cellphones, or because the introduction of coverage substantially increases reporting. ${ }^{18}$

There is ample evidence that some players in the Iraqi insurgency felt that cellphone networks were a boon to insurgents. In addition to facilitating improved coordination, cellphone service opened up a range of fusing options for IEDs. With cellular coverage, insurgents could call phones to detonate bombs, they could set up bombs that would detonate when coalition jammers terminated a call, and they could communicate between spotters and those controlling an explosive, meaning that the controller no longer needed to be within line-of-sight of the IED. ${ }^{19}$ Given the manifest potential military advantages to insurgents of having cellphones, it is perhaps not too surprising that in 2005 the chairman of the Iraqi National Communications and Media Commission reported companies were being "threatened by terrorists for delays in setting up masts" because "terrorists like mobile companies." 20

Cellphone technology, however, can also improve information gathering by counterinsurgent forces, which would in turn lead to more effective counterinsurgency and a decrease in violence. The two key mechanisms that account for this are best understood in the context of the Hearts-and-Minds (HAM) model. The model is formally presented in previous work, so we focus on a nontechnical discussion in this article. ${ }^{21}$

18. Applying the approach to comparing the potential bias from unobservables to that removed by controlling for observables suggested by Bellows and Miguel 2009 (outlined in the online appendix A) and used in Nunn and Wantchekon 2011 suggests that the size of this time-varying reporting bias would have to be roughly 78 percent as large as the time-invariant bias explained by cell fixed-effects but not by geographic covariates. That seems a large amount to fully account for the correlation but does suggest the average effect is probably substantially smaller than the coefficient estimates suggest. Private communications with authors, 29 March 2013.

19. See online appendix Figure A01.

20. Ryhs Blakely, “Terrorists 'Threaten' Iraq Mobile Operators," The Times (Internet ed.), 22 July 2005.

21. See Berman, Shapiro, and Felter 2011; and Berman, Felter, Shapiro, and Troland 2013. 
The HAM model is a three-sided game between violent rebels seeking to impose costs on a government, a government seeking to minimize violence by a mix of militarized counterinsurgency efforts and service provision, and civilians deciding whether to share information about insurgents. Civilian decisions are based on their political preferences, the benefits of government service provision, the costs imposed on them by rebel violence, and the ability of rebels to retaliate against community members who share information. In equilibrium, rebels produce violence up to a "noncooperation constraint," the point at which the externalities of violence to the community are so high that the representative community member is indifferent between sharing information with the government or not, given their political preferences and exposure to rebel retaliation. ${ }^{22}$ In extensions to the core model, Berman, Shapiro, and Felter show that the noncooperation constraint occurs at lower levels of insurgent violence when (1) the level of collateral damage caused by government forces at a given level of military activity is lower; and (2) the ability of rebels to retaliate against those who share information is reduced. ${ }^{23}$

Both of these parameters are directly affected by the introduction of cellphone technology. First, by using cellphone tracking and intercepted communications, counterinsurgent forces can target the most influential insurgents and therefore use force in ways that pose less risk to innocent civilians. This "signals intelligence" mechanism corresponds to the first extension above. Second, cellphones make it easier for the civilian population to share information with counterinsurgents because they make it possible to place calls from more private places than with fixed land-line phones (of which there was not great market penetration in Iraq in any case), allow for text messaging that cannot be overheard, and reduce the need for in-person meetings between government sources and their handlers. Cellphones thus reduce the insurgents' ability to identify and retaliate against people providing information. This "human intelligence" mechanism corresponds to the second extension. $^{24}$

There is anecdotal evidence that both mechanisms were at work in Iraq. It was cellphone monitoring, in part, that helped US forces kill several senior al-Qa'ida leaders in Iraq including Abu Musab al-Zarqawi and many others (as well as Osama Bin Laden in Pakistan). ${ }^{25}$ At the same time, coalition forces considered human intelligence to be key and worked throughout the war to make it safer for people to provide it. Shortly after the invasion in 2003, the National Tips Hot Line was rolled out by the Coalition Provisional Authority with nearly $\$ 10$ million budgeted

22. Biddle, Friedman, and Shapiro 2012 provide evidence that in many places in Anbar governorate anger at the externalities created by al-Qa'ida in Iraq violence led locals to turn against that insurgent group.

23. Berman, Shapiro, and Felter 2011.

24. In the HAM model as presented in ibid., the impact of cellular communications through these mechanisms would not depend on community norms ( $n$ in that model) because the authors assume an additive subutility function. Under other assumptions one could get different results.

25. Cal Perry, Jamie McIntyre, Barbara Starr, Henry Schuster, and Randa Habib, "Cellphone Tracking Helped Find al-Zarqawi," CNN (Internet ed.), 9 June 2006. 
for billboard, print, radio, and television advertising. ${ }^{26}$ Throughout Baghdad in 2004, the tip line was advertised as a way to "fight the war in secret." 27 Soldiers in many areas carried cards advertising tip lines. ${ }^{28}$ The idea behind these efforts was that many civilians opposed the insurgency enough to share useful information if they could do so safely, but not enough to take up arms on their own or join the police. ${ }^{29}$

If cellphone technology affects insurgency in the way the HAM model predicts, there should be a general decline in violence associated with the introduction of this technology in conflict regions. This constitutes our first hypothesis, and establishing the causal direction of this effect is our main goal. However, our analysis does not stop here. Even if we can establish a general effect, we still do not know which mechanism is responsible for it. Direct tests of the signals and human intelligence mechanisms, however, are difficult, if not impossible. There exists no unclassified data on such information transfers; in fact, intelligence from human sources (HUMINT) is among the most highly classified types of information held by the US military. Concrete data on cellphone tracking is impossible to get because of similar sensitivities around signals intelligence (SIGINT).

Instead, by examining effects across different kinds of attacks and at different levels of geographic aggregation, we can make the cautious case about how our results are consistent (or not) with different mechanisms. In particular, we distinguish between the effects of cellphone coverage in larger geographic units, and those in the direct vicinity of new cellphone towers. The former is relevant because insurgent violence need not be carried out where it is planned; rather, insurgents operate in a larger geographic radius. If we assume that cellphone coverage affects the planning stage of insurgent attacks or allows counterinsurgents to better target senior insurgents, we should study this effect in that area. Our first test thus focuses on administrative districts as unit of analysis. ${ }^{30} \mathrm{We}$ conduct a second analysis at a finer resolution, the coverage area around cellphone towers. These coverage areas typically have a radius of a few kilometers, and mostly correspond to small villages or settlements. This analysis intends to identify towers' influence on local tactical dynamics, either by making it

26. Kirk Semple, "US Backs Hot Line in Iraq to Solicit Tips About Trouble" New York Times (Internet ed.), 4 November 2006. This form of local intelligence is of course not unique to insurgencies; police forces consider local communities to be key sources of information for preventing crime and terrorism, and ongoing policing efforts focus on forging trust and confidence between citizens and security forces. See, for example, Innes 2006.

27. Donna Miles, "Hotline Succeeding in Foiling Iraqi Insurgents," American Forces Press Service (Internet ed.), 29 December 2004.

28. Such as the one shown in online appendix Figure A02 that was distributed by soldiers of the US Army 3rd Infantry Division operating in al-Zubayr, near Basrah, in 2010.

29. When a special operations task unit worked with Iraqna (Zain's predecessor) in early spring 2007 to reestablish cellphone coverage west of Fallujah for the first time in two years, the response was exactly what the HAM model would expect; the intelligence gathering and passing capabilities of the anti-insurgent movement grew dramatically, enabling a range of anti-insurgent operations by Coalition forces. Author interview with US Navy Commander Ryan Shann, 23 October 2012. Princeton, NJ.

30. There is good documentary evidence that one of the key insurgents groups in Iraq, al-Qa'ida in Iraq, organized along district lines, see Bahney et al. 2011, on Al-Qa'ida in Iraq. 
safer for people to share information or by enhancing the viability of remotely fusing IEDs and helping to coordinate ambushes.

The two levels of analysis give us some leverage in distinguishing between the human- and signals-intelligence mechanisms we describe. The signals-intelligence channel predicts that increased coverage will be violence reducing at the district level, but not at the coverage-area level. This is because the benefits of signals intercepts accrue in large part from understanding key individuals who operate widely and so can be attacked far from the location of the initial information acquisition. The information-sharing channel, in contrast, predicts that increased coverage should be violence-reducing at both levels because people living within a neighborhood are suddenly able to more safely share information about what is going on in their specific geographic space.

In sum, if cellphone communication affects insurgency according to the HAM model, we expect a general decrease in violence following the expansion of the network. If we see these effects both at the district- and the tower-level, that provides evidence for the human-intelligence mechanism. In contrast, identifying the effect at the district-level—but failure to do so at the tower level—constitutes evidence in favor of the signal-intelligence mechanism as the main one.

\section{Data and Identification Strategy}

Our analysis exploits variation in cellphone coverage introduced by the buildup of Iraq's network. We briefly describe the history of this network, our identification strategy, as well as our measure of violence and other control variables in our analysis.

\section{Iraq's Cellphone Network}

Under the regime of Saddam Hussein mobile communication was accessible to only a small minority of Iraqis, but the network has seen a rapid expansion in the recent years. Less than 10 percent of Iraq's population of approximately 25 million people lived in areas with cellphone coverage at the beginning of $2004 .{ }^{31}$ By February 2009, when our study period ends, Zain alone reported more than 10 million subscribers. ${ }^{32}$ After coalition forces had invaded Iraq and toppled Saddam in 2003, the establishment of modern communication networks was a priority during the reconstruction efforts. In late 2003, the Iraqi government sold contracts to establish cellphone networks to three companies, one for each of three regions

31. Authors' calculations based on coverage areas and Landscan population data.

32. Zain Iraq website is available at <http://www.iq.zain.com/iq/af/home.do?lang=en>, accessed 1 December 2014. 
(northern, southern, and central Iraq). To improve existing coverage and enable nationwide competition, the government auctioned three licenses for national coverage in fall 2007, which also led to the creation of a nationwide carrier, Zain.

The buildup of the cellphone network occurred in a phased approach, where providers first selected larger areas for expansion, and then chose specific sites for cellphone towers. ${ }^{33}$ According to what we were told, network expansion was only marginally affected by the ongoing insurgency, both because larger expansion areas were selected at the beginning of each year based on marketing considerations, and because local placement of towers was affected by a variety of administrative procedures orthogonal to the ongoing conflict.

We use data on the coverage of the cellphone network that Zain made available to us. It covers the period 2004 to 2009. Since Zain purchased other providers operating in central and southern Iraq in 2007 and 2008, our data include the majority of towers operating in areas of Iraq experiencing violence between 2004 and 2008. The original data set records information on 7,687 cellphone antennas with their precise on-air date and geographic location. Antennas were installed in groups of two or three per cellphone tower, so that together they provided a roughly 360-degree coverage around the tower. From the original data set we derived a tower data set of 2,489 unique locations. Because of missing on-air dates, seventy-three of these towers were dropped, which left 2,416 towers included in the analysis. Figure 1 shows the expansion of the Iraqi cellular network.

\section{Dependent Variable and Controls}

Our measure of insurgent violence includes attacks against Coalition and Iraqi government forces, and is based on 193,264 "significant activity" (SIGACT) reports by Coalition forces. These reports capture a wide variety of information about "executed enemy attacks targeted against coalition, ISF [Iraqi Security Forces], civilians, Iraqi infrastructure and government organizations" occurring between 4 February 2004 and 24 February 2009. ${ }^{34}$ Unclassified data drawn from the MNF-I SIGACTS-III Database were provided to the Empirical Studies of Conflict (ESOC) project in 2008 and 2009. These data provide the location, date, time, and type of attack incidents but do not include any information pertaining to the Coalition Force units involved, Coalition Force casualties, or battle damage incurred. We filter the data to remove attacks we can identify as being directed at civilians or other insurgent groups, leaving us with a sample of 168,730 attack incidents. ${ }^{35}$ Depending on

33. We give a detailed account of this procedure and its practical details in online appendix A03, based on information from MEC Gulf, a consulting firm that advised cellphone companies (including Zain) on network expansion, as well as conversations with the chief technology officers of the major Iraqi cellular firms.

34. US Department of Defense 2008, 24. See also US Government Accountability Office 2007.

35. We thank Lee Ewing for suggesting the filters we applied. 

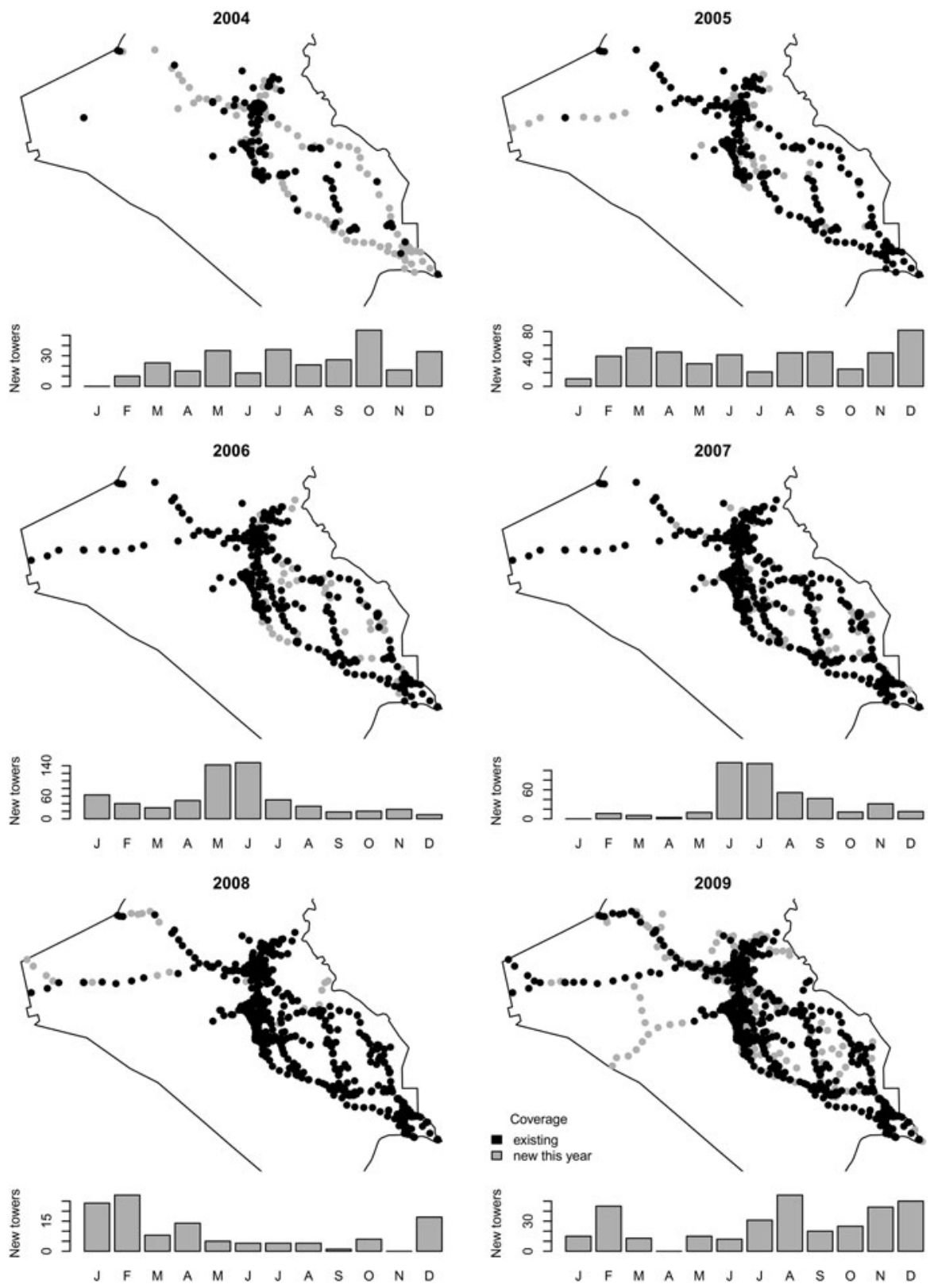

FIGURE 1. Expansion of the Zain Iraq network, 2004-2009 
level of analysis, we aggregate these events either at the level of districts or tower coverage areas.

To estimate the population we employ the fine-grained population data from LandScan aggregated to the district level. ${ }^{36}$ We estimated each district's ethnic composition by combining these data with precise ethnic maps of Iraq. After collecting every map we could find of Iraq's ethnic mix, we geo-referenced them and combined them with the population data to generate estimates of the proportion of each district's population that fell into each of the three main groups (Sunni, Shia, Kurd). We coded districts as mixed if no ethnic group had more than 66 percent of the population, otherwise the district was coded as belonging to its dominant ethnic group. There were large population movements during the war, but the sectarian changes were concentrated in Baghdad and there they occurred mostly neighborhood-to-neighborhood, at smaller geographic units than we are using.

\section{Identification Strategy}

Examining the impacts of coverage at both levels of geographic aggregation is important for two reasons. First, because we cannot test the hypothesized mechanisms of information sharing directly, we can use results at multiple levels of geographic aggregation to narrow down the mechanisms at work. Second, this approach is critical for assessing the policy relevance of the results. Results for smaller geographic units have ambiguous implications because coverage could reduce violence in small areas by reducing overall insurgent capacity, or by pushing insurgents to conduct attacks elsewhere (spatial displacement). We therefore conduct our analysis at two levels of analysis, the district and the tower level.

District-level Empirical Approach. At the district level we employ a standard panel data approach that is justified to the extent that we believe that controlling for factors such as the number of preexisting towers in a district, or time and space fixed-effects, will account for core drivers of network expansion that are also correlated with violence. ${ }^{37} \mathrm{We}$ might, for example, be concerned that expansion of the network is influenced by economic activity, which appears to be positively correlated with insurgent violence in Iraq, ${ }^{38}$ and so want to estimate the impact of coverage on violence in first-differences to account for unit-specific trends. ${ }^{39}$ So how viable is this approach?

36. Oak Ridge National Laboratory 2008.

37. Online appendix Table A04 shows descriptive statistics for the district-level data, which includes only the sixty-three districts in which Zain operated during the period of analysis.

38. Berman et al. 2011.

39. Formally, we can correctly identify the causal effect of network expansion if the treatment (month-tomonth changes in the network) is independent of the outcome (insurgent violence) conditional on controls. 
Given what we know about how the network was built, ${ }^{40}$ it is extremely unlikely that month-to-month variation in violence affected the network's construction. In numerous conversations with those who built the network, nobody reported major design changes being made in response to existing or anticipated insurgent violence. Site acquisition teams were reportedly able to build towers even in the context of difficult security situations such as Fallujah in 2004 and Ramadi in 2006. The teams would typically enter into long-term contracts with community members to pay for site rental, generator fueling, and site security, as well as training local engineers to provide these services. Where possible, they worked through local elites to identify the personnel who could be entrusted with these jobs. This strategy meant that once marketing had identified an area for network expansion, teams were able to move effectively even in areas with high violence.

However, many factors orthogonal to violence clearly did influence tower construction, often in ways that lead us to believe the month-to-month timing had a large random component. Towers were delayed because of unpredictable decisions by government officials, difficulties in identifying whether a potential lessor actually held title to the desired site, and disputes that arose once a site had been selected because the value of the lease and servicing contracts drew interested parties to make claims to land. Given these risks, the major firms employed what they described as a "scattershot" approach in which they would try to secure title to all of the sites in their expansion plan as soon as site selection was complete. As a practical matter, this meant they often built out in a different order than the marketing or service provision priorities alone would have dictated.

The variability in the rate of new tower construction highlights two patterns. ${ }^{41}$ First, there is tremendous month-to-month variation in the rate of new tower introduction, both within periods of high violence and during periods of peace. Second, there appears to be some correlation between extremely high violence and low tower introduction in a few places (Al-Muqdadiyah in Baghdad in 2007 for example), and nationally from August 2006 to July 2007. Adequately controlling for broad secular trends is therefore key to estimating the effect of towers on violence.

To conduct a more direct test of whether tower construction at the district level was consistently influenced by violence trends, we plot the average date of tower introduction within a district in a given year on the levels of violence in (1) the last six months of violence in the previous year and (2) the first six months of violence in a given year. If tower construction was delayed by levels of violence at the end of the previous year, which made it harder to adjudicate titles, that would have led to a positive slope as the average date of introduction was pushed back. If towers were introduced in ways that avoided violent districts, we should see a positive slope for the second plot because tower construction teams avoid highly violent places and so delay construction. 


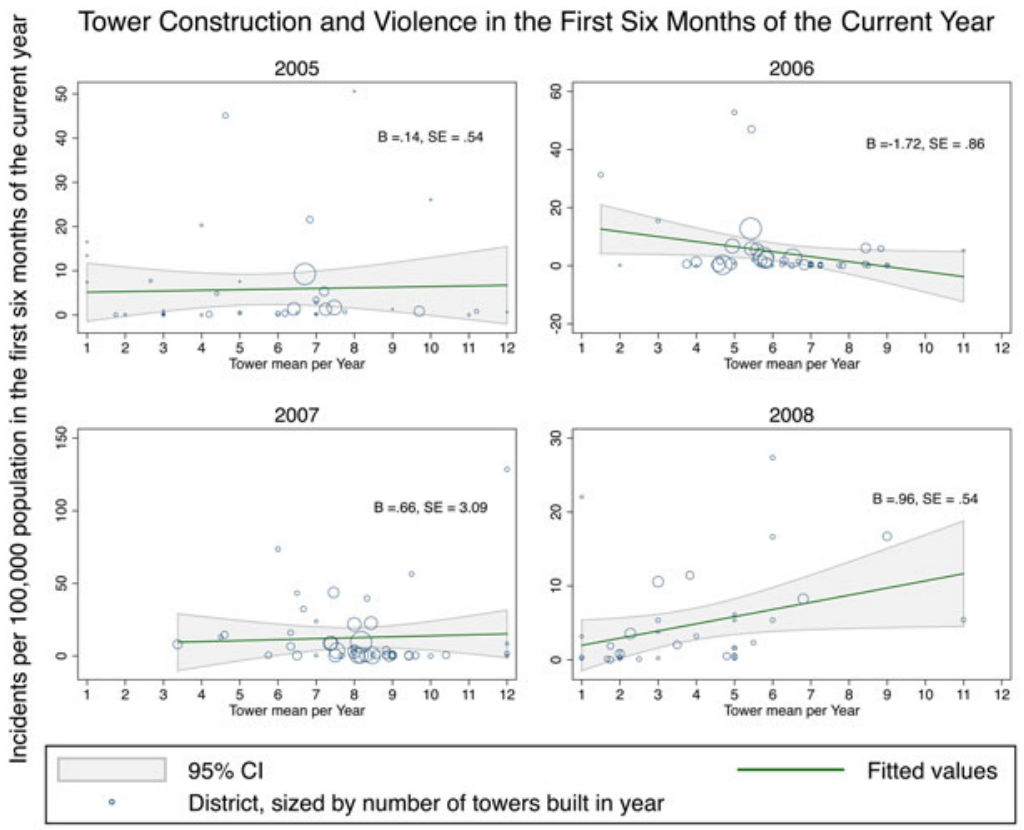

Tower Construction and Violence in the Last Six Months of the Previous Year
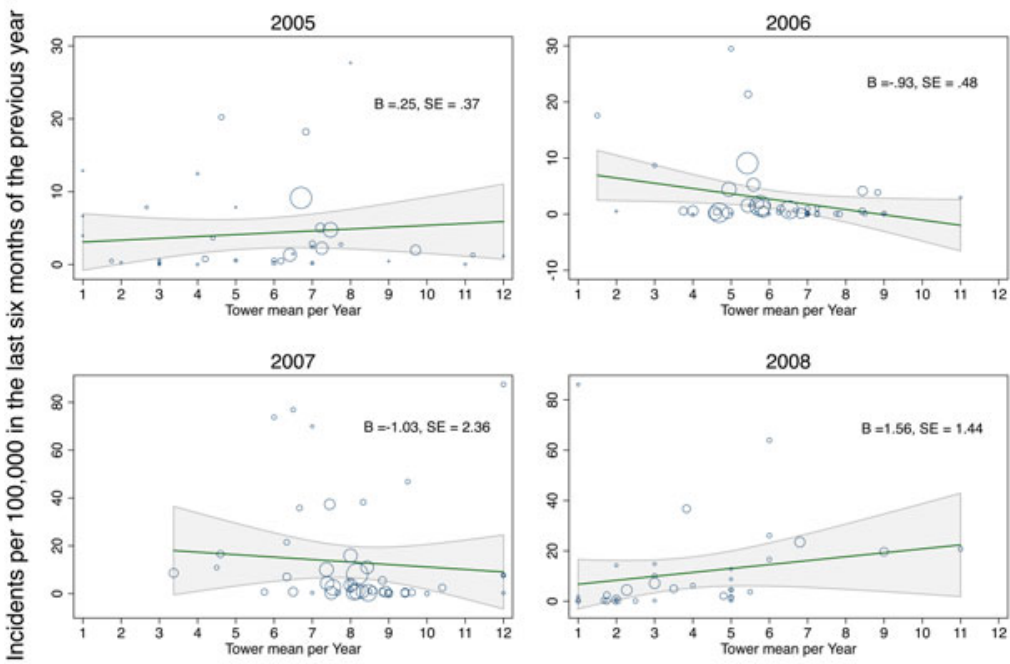

$95 \% \mathrm{Cl}$

Fitted values

District, sized by number of towers built in year

Notes: Unit of analysis for violence is district/half-year, July 2004 - December 2008. Violent events based on data on MNF-I SIGACT-III database. Cell tower data provided by Zain Iraq. Population data from Oak Ridge National Laboratory (2008) gridded population data. 
Neither was the case. Figure 2 shows that there is no consistent pattern across years at the district level. The top panel shows the relationship between levels of violence in the last six months of a year (plotted on the y-axis) and the average date of tower introduction in the next year (plotted on the x-axis). The bottom panel shows the relationship across years between levels of violence in the first six months of a year (plotted on the y-axis) and the mean date of tower introduction (plotted on the bottom panel). Only one of the bivariate correlations shown in the figure is statistically significant at the 95 percent level (the relationship between average date of tower introduction and violence in the direst six months of the current year), and that one is in the opposite of the expected direction. All these correlations become substantively small and statistically insignificant when the years are pooled or when sect fixed-effects are added to account for the average differences between purely Sunni regions where the nationalist insurgency dominated, and mixed regions that faced both a nationalist insurgency and a sectarian civil war. ${ }^{42}$

Our core specification at the district level is therefore a first-differences approach,

$$
\left.v_{i, t+1}-v_{i, t}=\alpha+\beta_{1} \text { towers }_{i, t}-\text { towers }_{i, t-1}\right)+f_{i}+\delta_{t}+\varepsilon_{i, t}
$$

where $f_{i}$ is a district fixed-effect and $\delta_{t}$ is a time fixed-effect. We lag the difference in tower construction by one month to prevent simultaneity bias. ${ }^{43}$

Importantly, to provide an unbiased estimate of the impact of cellphone coverage on violence the requirement for this approach is not that we control for all other factors that could affect violence. Rather, it is that the fixed-effects control for those factors that are also correlated with both changes in the number of towers and changes in levels of violence. Based on what we know about the process of expanding the network, none of the factors affecting the month-to-month timing of the introduction of towers (for example, the availability of clean titles to desired locations) are likely to vary in ways not accounted for by time and space fixedeffects. ${ }^{44}$ Figure 2 provides strong evidence that they did not and we will show that our results are robust to the inclusion of a broad range of time and space fixed-effects. More importantly, the core results pass both geographic and temporal placebo tests, providing confidence that the results are not driven by district-specific

42. A similar plot for the violence in the last six months of the current year is shown in online appendix Figure A07. Results of regressions pooling across years and adding controls to account for differences between them are shown in online appendix Table A08.

43. We believe the first-differences specification is the right one in this application-as opposed to estimating the model in levels with a unit fixed-effect-because we are more concerned with controlling for unit-specific trends in potential confounders than in unit-specific means. The war followed very different trajectories in each district: see, for example, Figure A05 in the online appendix; Fig. 1 in Berman, Shapiro, Felter 2011; or Fig. 2 and suppl. Fig. 4 in Biddle, Friedman, and Shapiro 2012. As a general matter, violence in these districts did not vary around some mean for most of the war. Most districts saw a strong upward trend until sometime in 2006 or 2007 and then a strong downward trend.

44. As we will discuss, online appendix A12 checks for the possibility that past sectarian violence is an omitted variable impacting both the difficulty of obtaining title and trends in violence, finding no evidence that it is. 
trends or by region-specific omitted variables. We also control for Coalition force levels because one might imagine their presence facilitated both tower introduction and changes in violence.

Tower-level Empirical Approach. For our tower-level analysis, we require approximations of the towers' coverage areas. We approximate the coverage of individual towers by a circular area. Depending on whether a tower is located in an urban or rural area, we assign a short radius or a long radius. In conversations with electrical engineers we determined radii of four and twelve kilometers to be good first-order approximations of the coverage areas given the equipment used on the towers and their spacing, respectively, but we also conduct robustness checks with alternative ones. ${ }^{45}$ Estimating more precise coverage areas entails substantial complications and so for purposes of this paper we restrict ourselves to approximating coverage.

The key to our tower-level approach is that some towers simply enhance service that was already available, while other towers extend service into new areas. If violence declines because towers are introduced, and not because of some omitted variable driving introduction and violence, we should see that violence goes down around towers that provide new coverage, but not around those that simply enhance existing service. If, however, violence declines because of some omitted variable, say because the providers are good at anticipating where violence will drop, we should see post-introduction declines in both areas.

An effective way to implement this approach is to use a standard difference-in-differences design where our estimate of the treatment effect is just $\mathrm{E}\left[\left(\mathbf{a}_{\text {post }}-\mathbf{a}_{\text {pre }}\right)\right.$ $\left.\left(\mathbf{b}_{\text {post }}-\mathbf{b}_{\text {pre }}\right)\right]$ where $\mathbf{a}$ is a vector of violence in towers that provide new coverage and $\mathbf{b}$ is the analogous vector for towers that simply deepen existing coverage. This logic gives us the following tower-level estimating equation:

$$
v_{i, t}=\beta_{1} \text { post }_{t}+\beta_{2}\left(\text { post }_{t} \times n e w_{i}\right)+f_{i}+q_{t}+\varepsilon_{i, t}
$$

where $f_{i}$ is a slice fixed-effect, $q_{t}$ is a quarter fixed-effect to control for secular trends in the conflict, the post $t_{t}$ variable is a dummy variable that takes a value of 1 after tower introduction, and post $_{t} \times n e w_{i}$ is a dummy variable that takes a value of 1 in new coverage areas after towers are turned on. Since the threshold for what should constitute a new coverage area is not obvious-Zain always sought some overlap so there are almost no entirely new areas-our core analysis shows what happens as we vary the threshold for being a "new" tower from 10 percent new coverage to 90 percent. The key coefficient to focus on is $\beta_{2}$, which tells us how much the trend around towers that provide substantial new coverage differs from the trend around similar towers that extend existing coverage.

45. Precise coverage estimates do not exist for Iraq and all major modeling software requires substantial input we have not been able to get from Zain. The twelve kilometer and four kilometer data are based on an extensive effort to precisely model Zain's coverage with colleagues in electrical engineering, Professor Mung Chiang and Dr. Haris Kremo. Details available on request. 
Of the 1,859 coverage areas created by towers established between 14 June 2004 and 26 October 2008, 1,787 areas experienced at least one violence incident in our data. ${ }^{46}$ These are the slices for which we have eight full fifteen-day periods of violence data (120 days) before and after the towers were established. Towers reinforcing existing coverage typically serve larger populations and experience more total violence, though substantially less per capita. This is, of course, because few new towers are needed in sparsely populated rural areas, while increasing adoption of cellphones created demand for greater capacity in urban areas, requiring Zain to introduce more towers and "split cells" to maintain service and maximize its profits. Under the identifying assumption for the difference-in-differences estimate, that differencing accounts for unit-specific characteristics, these time-invariant differences in slices should not bias the estimation, though we will discuss how it might and why we think it unlikely.

\section{Results}

To analyze the impact of expanding the cellphone network on violence, we first analyze district-level effects using standard panel data techniques, and provide a series of robustness checks. Second, we briefly describe additional results by attack type and sectarian area, the details for which can be found in the online appendix. Third, we analyze the effect of introducing coverage over towers' coverage areas.

\section{District-level}

At the district level, we find that adding additional cellphone coverage decreases violence. Table 1 presents the core specification in first differences that nets out districtspecific factors such as the anticipated long-term economic value of the district, which might have an impact on trends in both insurgent violence and the introduction of cellphones. The results in differences are smaller but remain statistically significant once we control for national changes using time fixed-effects for the quarter-year (column 2) or month (column 3). Adding a district fixed-effect in addition to differencing (column 4) shows the results are robust to controlling for time-invariant district effects in addition to district-specific trends. Allowing the fixed-effects to vary across the intersections of time and ethnic regions in columns (5 and 6) accounts for the fact that trends in the war were quite heterogeneous across different regions. The peak violence in Anbar province where Sunni tribes were fighting a nationalist insurgency, for example, came six months before violence peaked in 
TABLE 1. Impact of increased cellphone coverage on total attacks—district/month

\begin{tabular}{|c|c|c|c|c|c|c|c|}
\hline Dependent variable & (1) & (2) & (3) & $\begin{array}{c}\text { (4) } \\
\text { First difference }\end{array}$ & (5) & (6) & (7) \\
\hline Lagged first difference of tower count & $\begin{array}{c}-0.0780 \\
(0.047)\end{array}$ & $\begin{array}{c}-0.0882 * \\
(0.049)\end{array}$ & $\begin{array}{c}-0.115^{* *} \\
(0.056)\end{array}$ & $\begin{array}{c}-0.149 * * \\
(0.070)\end{array}$ & $\begin{array}{c}-0.0887^{*} \\
(0.054)\end{array}$ & $\begin{array}{c}-0.0952 * \\
(0.055)\end{array}$ & $\begin{array}{c}-0.188^{*} \\
(0.11)\end{array}$ \\
\hline Observations & 3,654 & 3,654 & 3,654 & 3,654 & 3,654 & 3,654 & 3,654 \\
\hline$R$-squared & 0.01 & 0.01 & 0.07 & 0.07 & 0.03 & 0.06 & 0.07 \\
\hline Time fixed-effects & Half & Quarter & Month & Month & Sect $X$ half & Sect $\mathrm{X}$ quarter & Province $\mathrm{X}$ quarter \\
\hline Space fixed-effects & No & No & No & District & No & No & No \\
\hline
\end{tabular}

Notes: Unit of analysis for violence is district/month, February 2004 to January 2009. Violent events based on data on MNF-I SIGACT-III database. Cell tower data provided by Zain Iraq Population data from Oak Ridge National Laboratory (2008) gridded population data and World Food Programme surveys (2004, 2006, and 2008). Analysis restricted to sixty-three districts in which Zain operated during period under study. Sect variable classifies districts as Sunni, Shia, Kurdish, or mixed. Robust standard errors, clustered at the district level in parentheses. Significance shown as $* p<.10 ; * * p<.05 ; * * *<.01$ 
Baghdad where Sunni and Shia militias were engaged in a sectarian conflict. The results remain substantively similar and statistically strong even when we include a district fixed-effect and net out the average violence in the each of the thirteen provinces each quarter (column 7), an extremely robust way to control for the geographically specific trends in the conflict and in incentives to build towers. ${ }^{47}$

Overall, the introduction of new towers correlates with less violence no matter how we handle secular trends in violence. In the most stringent model, column (7), a one standard deviation increase in the number of towers in a district (1.8) predicts 1.1 less attacks $(-.188 \times 3.27 \times 1.8)$ in the following month, a 10 percent decrease from the mean level of violence. ${ }^{48}$ In the online appendix ${ }^{49}$ we provide tests that suggest the results are not driven by: (1) omitted variables driving trends in both violence and tower construction; (2) the direct impact of violence on future tower construction; or (3) enhanced coverage making insurgents more effective, allowing them to conduct more lethal attacks (for example, shifting from a large number of small ambushes to a small number of large complex attacks). Taken together, these checks provide additional confidence that the combination of differencing and fixedeffects in Table 1 properly identify the causal impact of tower construction at the district-month level.

Finally, as we show in the online appendix, ${ }^{50}$ the results become substantially stronger when we restrict attention to district/months where the proportion of the population covered was not yet high. This suggests that towers covering new geographic territory, as opposed to those that simply enhance the capacity of the network, are driving the result. We will see this pattern again in the tower-level analysis.

\section{Variation in District-level Effects}

The effect of expanded cellphone coverage on insurgent attacks varies in informative ways across different insurgent tactics and across sectarian areas. Different kinds of insurgent attacks have different sensitivities to the productivity of labor and to information sharing by the population. In particular, direct fire attacks (for example, ambushes) typically involve multiple individuals coordinating their actions but they are sensitive to information sharing by the population, which can observe insurgents setting up. Indirect fire attacks (for example, mortars) require less coordination and are less sensitive to information sharing as insurgents have great flexibility in choosing their firing position. IED attacks require much less coordination around the point of attack than direct fire attacks and reveal less information to non-combatants, but

47. Online appendix Table A10 shows the results of the most stringent specifications (columns 4 and 7) are robust to the inclusion of the spatial lag of violence as an additional control.

48. These effects fade after about two months, as online appendix Figure A11 shows.

49. See online appendix Tables A12-A14.

50. See online appendix Table A15. 
remain sensitive to tips relative to indirect fire attacks, especially since tips about weapons caches can remove a large number of IEDs from circulation. ${ }^{51}$

As Table 2 shows, adding towers reduces all types of attacks, but has heterogeneous effects across the three main attack types. Panel (A) of Table 2 reports the core first differences model for each type of attack with district and month fixedeffects, analogous to column (7) of Table 1. The effect is negative, but not statistically significant for direct fire attacks and positive but not statistically significant for indirect fire attacks. The effect is negative and statistically significant for total IED attacks attempted. The substantive effects are meaningful but not large. A one standard deviation increase in the number of towers introduced reduces the number of direct fire attacks in an average district-month by approximately 6.5 percent, and reduces the number of IEDs attempted by approximately 8.1 percent. Further panels check for potential sources of bias by showing the results remain substantially unchanged when we: include a spatial lag of the dependent variable to account in a rough way for spatial autocorrelation (Panel B); drop the period when the number of towers being introduced was increasing but there was a strong secular trend in attacks (Panel C); allow for period-specific district fixed-effects to account for the clearly lower rate of tower introduction at the peak of the war (Panel D); or control directly for Coalition Force levels that might correlate with both tower introduction and trends in violence (Panel E). ${ }^{52}$

What about variation across different sectarian areas? As Table 3 shows, it turns out that the results are substantively strongest in Sunni areas where per capita violence was highest. Column (1) of the table reports our core first differences specification, and the remaining columns report the results for different sectarian subsets of the data. Column (5) combines Sunni and mixed areas, showing that the average effect across the parts of the country where the war was really fought is negative and substantively modest, so that a one standard deviation increase in towers in these areas led to 3.9 fewer attacks in the next month $(1.9 \times-.496 \times 4.176)$, a 12.3 percent reduction. Column (6) reports the results for ethnically homogenous districts, where 80 percent of the population or more is from one sect, and column (7) shows the results for nonhomogenous districts. The effects are substantively similar across these areas, with the standard errors being much larger in the nonhomogenous districts because of the smaller sample size. The online appendix breaks these results down by both attack type and sectarian region, showing that the effects are driven by Sunni and mixed areas, which makes sense considering there were relatively few insurgent attacks in Shia and Kurdish districts, and that the reduction in direct fire attacks is strongest in Sunni areas is far and away the strongest effect. ${ }^{53}$

51. Direct fire weapons such as AK-47s are ubiquitous throughout Iraq and so their supply is unlikely to be as sensitive to raids being conducted on the basis of tips.

52. We thank Carrie Lee for generously sharing her data on the number of Coalition maneuver battalions (forces who could actually patrol, run raids, and attack insurgents directly) present per district month (Lindsay 2011).

53. See online appendix Table A16. 
TABLE 2. Impact of increased cellphone coverage by attack type

\begin{tabular}{|c|c|c|c|c|c|}
\hline $\begin{array}{l}\text { Dependent variable: First } \\
\text { difference of attacks/ } \\
100,000\end{array}$ & (1) All attacks & (2) Direct fire & $\begin{array}{l}\text { (3) Indirect } \\
\text { fire }\end{array}$ & $\begin{array}{l}\text { (4) Total IED } \\
\text { attempts }\end{array}$ & $\begin{array}{l}\text { (5) IEDs cleared/ } \\
\text { total attempts }\end{array}$ \\
\hline \multicolumn{6}{|c|}{ Panel A: Full sample } \\
\hline \multirow{2}{*}{$\begin{array}{l}\text { Lagged first difference of } \\
\text { tower count }\end{array}$} & $-0.149^{* *}$ & -0.0449 & 0.00525 & $-0.065^{*}$ & -0.003 \\
\hline & $(0.070)$ & $(0.033)$ & $(0.0083)$ & $(0.037)$ & $(0.004)$ \\
\hline Observations & 3,654 & 3,654 & 3,654 & 3,654 & 1,701 \\
\hline$R$-squared & 0.07 & 0.03 & 0.09 & 0.05 & 0.02 \\
\hline \multicolumn{6}{|c|}{ Panel B: Full sample with spatial lag } \\
\hline \multirow{2}{*}{$\begin{array}{l}\text { Lagged first difference of } \\
\text { tower count }\end{array}$} & $-0.140 * *$ & -0.0443 & 0.0049 & $-0.056^{*}$ & -0.0027 \\
\hline & $(0.069)$ & $(0.033)$ & $(0.008)$ & $(0.032)$ & $(0.004)$ \\
\hline \multirow{2}{*}{$\begin{array}{l}\text { Spatial lag of dependent } \\
\text { variable }\end{array}$} & $0.0323 * * *$ & $0.0106^{* *}$ & 0.0022 & $0.0433 * * *$ & -0.0326 \\
\hline & $(0.008)$ & $(0.0042)$ & $(0.004)$ & $(0.013)$ & $(0.030)$ \\
\hline Observations & 3,654 & 3,654 & 3,654 & 3,654 & 1,701 \\
\hline \multirow[t]{2}{*}{$R$-squared } & 0.12 & 0.04 & 0.09 & 0.12 & 0.02 \\
\hline & \multicolumn{4}{|c|}{ Panel C: Without 2008} & \\
\hline \multirow{2}{*}{$\begin{array}{l}\text { Lagged first difference of } \\
\text { tower count }\end{array}$} & $-0.184 * *$ & $-0.0631^{*}$ & 0.0045 & $-0.075 * *$ & -0.0006 \\
\hline & $(0.075)$ & $(0.037)$ & $(0.009)$ & $(0.036)$ & $(0.004)$ \\
\hline Observations & 2,898 & 2,898 & 2,898 & 2,898 & 945 \\
\hline$R$-squared & 0.07 & 0.03 & 0.09 & 0.06 & 0.03 \\
\hline \multicolumn{6}{|c|}{ Panel D: With period-specific district fixed-effects (period breaks at August 2006 and June 2007) } \\
\hline \multirow{2}{*}{$\begin{array}{l}\text { Lagged first difference of } \\
\text { tower count }\end{array}$} & $-0.149^{* *}$ & -0.050 & 0.007 & $-0.062 *$ & -0.0032 \\
\hline & $(0.068)$ & $(0.034)$ & $(0.008)$ & $(0.034)$ & $(0.005)$ \\
\hline Observations & 3,654 & 3,654 & 3,654 & 3,654 & 1,701 \\
\hline \multirow[t]{2}{*}{$R$-squared } & 0.11 & 0.05 & 0.12 & 0.08 & 0.02 \\
\hline & Panel E: & Controlling for & alition force $l$ & & \\
\hline \multirow{2}{*}{$\begin{array}{l}\text { Lagged first difference of } \\
\text { tower count }\end{array}$} & $-0.150 * *$ & -0.047 & 0.0051 & $-0.064 *$ & -0.0018 \\
\hline & $(0.070)$ & (0.034) & (0.0084) & (0.033) & $(0.004)$ \\
\hline Observations & 3,528 & 3,528 & 3,528 & 3,528 & 1,575 \\
\hline$R$-squared & 0.071 & 0.034 & 0.090 & 0.055 & 0.032 \\
\hline
\end{tabular}

Notes: Unit of analysis for violence is district/month, February 2004 to January 2009. Violent events based on data on MNF-I SIGACT-III database. Cell tower data provided by Zain Iraq. Population data from Oak Ridge National

Laboratory (2008) gridded population data and World Food Programme surveys (2004, 2006, and 2008). Coalition force levels from Lindsay 2011. Analysis restricted to sixty-three districts in which Zain operated during period under study. Robust standard errors, clustered at the district level in parentheses. All results include district and month fixed-effects. Significance shown as $* p<.10 ; * * p<.05 ; * * * p<.01$.

These patterns imply first that the human-intelligence mechanism is key. Expanding coverage creates new collection channels for signals intelligence in all regions, but we expect the impact of providing people a safer way to share tips to be larger in Sunni areas because (1) Coalition forces' ability to run human sources would be weakest and (2) in-group policing by insurgents would be most effective. If the reader agrees with that expectation, then the fact that these areas see the largest proportional declines from introducing coverage should be suggestive. Second, the fact that the effects are of similar magnitude for direct fire and IED attacks (nearly identical if we drop 2008 from the analysis) makes it seem unlikely that expanding 
TABLE 3. Impact of increased cellphone coverage by sectarian area

\begin{tabular}{|c|c|c|c|c|c|c|c|}
\hline $\begin{array}{l}\text { Dependent variable: First difference of attacks/ } \\
100,000\end{array}$ & (1) All areas & (2) Mixed & (3) Kurd/Shia & (4) Sunni & (5) Mixed/Sunni & $\begin{array}{l}\text { (6) Ethnically } \\
\text { homogenous }\end{array}$ & (7) Nonhomogeneous \\
\hline Lagged first difference of tower count & $\begin{array}{l}-0.149 * * \\
(0.070)\end{array}$ & $\begin{array}{c}-0.251 \\
(0.19)\end{array}$ & $\begin{array}{c}-0.0096 \\
(0.058)\end{array}$ & $\begin{array}{l}-2.259^{*} \\
(1.07)\end{array}$ & $\begin{array}{c}-0.496^{*} \\
(0.29)\end{array}$ & $\begin{array}{c}-0.195^{* *} \\
(0.083)\end{array}$ & $\begin{array}{c}-0.184 \\
(0.15)\end{array}$ \\
\hline Observations & 3,654 & 580 & 2,436 & 638 & 1,218 & 2,784 & 870 \\
\hline Number of districts & 63 & 10 & 42 & 11 & 21 & 48 & 15 \\
\hline$R$-squared & 0.07 & 0.30 & 0.10 & 0.23 & 0.18 & 0.06 & 0.21 \\
\hline
\end{tabular}

Notes: Unit of analysis for violence is district/month, February 2004 to January 2009. Violent events based on data on MNF-I SIGACT-III database. Cell tower data provided by Zain Iraq. Population data from Oak Ridge National Laboratory (2008) gridded population data and World Food Programme surveys (2004, 2006, and 2008). Sectarian data from ESOC developed by attributing LandScan data according to maps by Michael Izady made available through the Gulf 2000 website. Analysis restricted to sixty-three districts in which Zain operated during period under study. Robust standard errors, clustered at the district level in parentheses. All results include month and district fixed-effects. Significance shown as $* p<.10 ; * * p<.05 ; * * * p<.01$. 
coverage substantially eased coordination. If it had, the effect on direct fire attacks, which require more coordination, should have been muted.

\section{Tower-level Results}

Our tower-level analysis employs a before/after difference-in-differences design that compares towers introducing new coverage ("new towers") with those that mainly reinforce existing one ("reinforcing towers").

Table 4 shows that mean levels of violence per fifteen-day period at the tower level are much lower in the 120 days after the on-air date for new towers, but not for reinforcing ones. Panel (A) shows the results of the standard difference-in-differences regression, which does not account for secular trends. Panel (B) shows the results controlling for broad secular trends with quarter fixed-effects. The difference is striking. The positive change in average per-period violence after introduction of a reinforcing tower that we see in panel (A) is an artifact of secular trends. Once quarter fixed-effects are added, the positive mean shift disappears but the negative mean shift in areas where towers add 10 percent or more new coverage remains substantively and statistically strong. Indeed, in panel (B) the reduction in violence from new towers is statistically robust and substantively consistent across coverage thresholds. At the 50 percent threshold, turning on a new tower predicts .896 fewer attacks per period, more

TABLE 4. Impact of introducing cellular communications for tower areas

\begin{tabular}{|c|c|c|c|c|c|}
\hline $\begin{array}{l}\text { Coverage threshold for "new" } \\
\text { towers }\end{array}$ & (1) $10 \%$ & (2) $30 \%$ & (3) $50 \%$ & (4) $70 \%$ & (5) $90 \%$ \\
\hline \multicolumn{6}{|c|}{ Panel A: Standard difference-in-differences } \\
\hline \multirow[t]{2}{*}{ Post } & $1.10^{* * *}$ & $1.01 * * *$ & $0.97 * * *$ & $0.93 * * *$ & $0.91 * * *$ \\
\hline & $(0.21)$ & $(0.19)$ & $(0.19)$ & $(0.19)$ & $(0.18)$ \\
\hline \multirow[t]{2}{*}{ Post $\times$ new } & $-1.02 * * *$ & $-0.90 * *$ & $-0.74 * * *$ & $-0.53 *$ & -0.44 \\
\hline & $(0.31)$ & $(0.37)$ & $(0.27)$ & $(0.28)$ & $(0.32)$ \\
\hline Observations & 29,744 & 29,744 & 29,744 & 29,744 & 29,744 \\
\hline Number of towers & 1,859 & 1,859 & 1,859 & 1,859 & 1,859 \\
\hline$R$-squared & 0.74 & 0.74 & 0.74 & 0.74 & 0.74 \\
\hline \multicolumn{6}{|c|}{ Panel B: Quarter fixed-effects to control for secular trends } \\
\hline Post & $\begin{array}{l}-0.07 \\
(0.20)\end{array}$ & $\begin{array}{c}-0.17 \\
(0.19)\end{array}$ & $\begin{array}{c}-0.22 \\
(0.18)\end{array}$ & $\begin{array}{c}-0.24 \\
(0.18)\end{array}$ & $\begin{array}{c}-0.26 \\
(0.18)\end{array}$ \\
\hline Post $\times$ new & $\begin{array}{c}-1.07 * * * \\
(0.32)\end{array}$ & $\begin{array}{c}-0.87^{* *} \\
(0.40)\end{array}$ & $\begin{array}{c}-0.67 * * \\
(0.32)\end{array}$ & $\begin{array}{c}-0.61 * \\
(0.34)\end{array}$ & $\begin{array}{c}-0.52 \\
(0.39)\end{array}$ \\
\hline Observations & 29,744 & 29,744 & 29,744 & 29,744 & 29,744 \\
\hline Number of towers & 1,859 & 1,859 & 1,859 & 1,859 & 1,859 \\
\hline$R$-squared & 0.75 & 0.75 & 0.75 & 0.75 & 0.75 \\
\hline
\end{tabular}

Notes: Unit of analysis for violence is tower/fifteen-day period. Tower coverage areas created by a four-kilometer radius around cellphone towers in urban areas and twelve-kilometer radius in rural areas. Violent events based on data on MNF-I SIGACT-III database. Cell tower data provided by Zain Iraq. Population data from Oak Ridge National Laboratory (2008) gridded population data. Includes only towers with at least eight periods before and after on-air date. Robust standard errors, clustered at the tower level in parentheses. All specifications include tower fixed-effects. Significance shown as $* p<.10 ; * * p<.05 ; * * * p<.01$. 
than half the mean level of violence in tower areas that provide 50 percent new coverage. The online appendix repeats the analysis of Table 4 dropping coverage areas that introduce intermediate levels of new coverage, that is, towers that cover between 10 percent new area and the threshold for being a "new" area in Panel A. ${ }^{54}$ The difference-in-difference estimate is substantively larger and more statistically significant at higher coverage thresholds with this specification, as it should be when the treatment contrast is between towers that introduce substantial new coverage and those that introduce no new coverage.

Once we net out the broad secular trends, it appears that introducing coverage is violence reducing at the local level, but that building reinforcing towers is not. Table 5 shows that, just as with the district-level results, the effect is statistically strongest for IED attacks. The impact of coverage is positive for indirect fire attacks but statistically insignificant for more lenient interpretations of what constitutes new coverage. This is consistent with an information mechanism insofar as it indicates tactical substitution wherein insurgents seeking to attack newly covered areas do so with methods that do not require that they physically go to those areas.

The tower-level effects do vary a bit by period, though the introduction of new coverage always reduces violence relative to overall trends in tower catchment areas that do not expand coverage. ${ }^{55}$ Panel A excludes towers turned on during the period in 2006-2007 when tower construction slowed. Panel B drops towers built after 2007. The results mirror those in the full sample because there is a clear negative impact of towers that provide at least 20 percent new coverage on IED attacks relative to the change in tower catchments that provide less than that. Our ability to control for broad secular trends in areas getting new towers is reduced when we exclude certain periods (the mean shift after reinforcing tower introduction is statistically significant in many of these models), however the core result that violence drops more in new tower catchments (the interaction term) remains robust.

The geographic nature of the spillovers from the introduction of new towers is also informative. If introducing new coverage simply pushed insurgents to relocate, then we might see a near term increase in attacks in a ring around new coverage areas. Alternatively, if new coverage made it easier for counterinsurgents to acquire information that facilitated raids that disrupt insurgent activity over a larger area, then we might expect violence to drop in the area adjacent to new towers, but not that adjacent to existing towers. The online appendix shows that insurgent violence drops faster in the four-kilometer ring around new coverage areas than in similarly sized rings around preexisting coverage areas. ${ }^{56}$ Since insurgents in Iraq organized in units that covered areas larger than immediate coverage areas this pattern is consistent

54. See online appendix Table A17.

55. Online appendix Table A18 reports these results by attack type.

56. See online appendix Table A17. Panel A reports the results from estimating equation (2) with violence in the ring around the coverage area as the LHS variable. Panel B reports the same specification adding controls for the contemporaneous number of attacks within the main coverage area. 
with our interpretation that the violence reduction engendered by turning on new coverage reflects an increased ability of counterinsurgents to act against militants.

TABLE 5. Impact of increased cellphone coverage by attack type at different thresholds

\begin{tabular}{|c|c|c|c|c|}
\hline Dependent variable & (1) All attacks & (2) Direct fire & (3) Indirect fire & (4) Total IED attempts \\
\hline \multicolumn{5}{|c|}{ Panel A: Coverage threshold for "new" towers $=20 \%$} \\
\hline \multirow[t]{2}{*}{ Post } & -0.15 & -0.17 & -0.021 & -0.074 \\
\hline & $(0.19)$ & $(0.11)$ & $(0.042)$ & $(0.088)$ \\
\hline \multirow[t]{2}{*}{ Post $\times$ new } & $-0.89 * *$ & -0.24 & 0.064 & $-0.42 * * *$ \\
\hline & $(0.37)$ & $(0.19)$ & $(0.050)$ & $(0.13)$ \\
\hline Observations & 29,744 & 29,744 & 29,744 & 29,744 \\
\hline$R$-squared & 0.75 & 0.64 & 0.31 & 0.80 \\
\hline \multicolumn{5}{|c|}{ Panel B: Coverage threshold for "new" towers $=50 \%$} \\
\hline \multirow[t]{2}{*}{ Post } & -0.22 & $-0.19^{*}$ & -0.025 & -0.090 \\
\hline & $(0.18)$ & $(0.10)$ & $(0.041)$ & $(0.085)$ \\
\hline \multirow[t]{2}{*}{ Post $\times$ new } & $-0.67 * *$ & -0.16 & $0.12 * *$ & $-0.45^{* * *}$ \\
\hline & $(0.32)$ & $(0.16)$ & $(0.056)$ & $(0.13)$ \\
\hline Observations & 29,744 & 29,744 & 29,744 & 29,744 \\
\hline \multirow[t]{2}{*}{$R$-squared } & 0.75 & 0.64 & 0.31 & 0.80 \\
\hline & Panel C: $C$ & ge threshold for & " towers $=80 \%$ & \\
\hline \multirow[t]{2}{*}{ Post } & -0.25 & $-0.20^{* *}$ & -0.024 & -0.11 \\
\hline & $(0.18)$ & $(0.097)$ & $(0.040)$ & $(0.083)$ \\
\hline \multirow[t]{2}{*}{ Post $\times$ new } & $-0.58^{*}$ & -0.14 & $0.16^{* * *}$ & $-0.42 * * *$ \\
\hline & $(0.35)$ & $(0.17)$ & $(0.058)$ & $(0.15)$ \\
\hline Observations & 29,744 & 29,744 & 29,744 & 29,744 \\
\hline$R$-squared & 0.75 & 0.64 & 0.31 & 0.80 \\
\hline
\end{tabular}

Notes: Unit of analysis for violence is tower/fifteen-day period. Tower coverage areas created by a four-kilometer radius around cellphone towers in urban areas and twelve-kilometer radius in rural areas. Violent events based on data on MNF-I SIGACT-III database. Cell tower data provided by Zain Iraq. Population data from Oak Ridge National Laboratory (2008) gridded population data. Includes only towers with at least eight periods before and after on-air date. Robust standard errors, clustered at the tower level in parentheses for 1,859 towers. All specifications include tower and quarter fixed-effects. Significance shown as $* p<.10 ; * * p<.05 ; * * p<.01$.

For one to believe the tower-level results are driven by omitted variable bias, the correlation between future violence and the week-to-week timing of where towers are placed would have to be massively stronger for new towers than for reinforcing towers installed at the same time. That seems unlikely, particularly since the correlation between the proportion of new coverage a tower provides and total violence over the 120 days after construction is negligible once district-specific violence has been taken into account. ${ }^{57}$

Overall then, the tower-level results provide additional evidence that the humanintelligence mechanism is driving the panel data results. Introducing cellphone coverage has a clear localized impact in reducing the number of IEDs in new coverage

57. In other words, controlling for violence at a level of geographic aggregation that is much larger than the tower-specific fixed-effects used in all the regressions in this section removes the correlation we would expect if there were a strong relationship between violence and the amount of new coverage towers provide. Results available on request. 
areas but not in previously covered ones. This is particularly striking considering that putting coverage over an area increases the range of IED fusing options that should, if anything, decrease the proportion counterinsurgents can successfully neutralize.

\section{Conclusion}

This article presents the first systematic examination of cellular communications' effect on political violence using novel micro-level data from Iraq. We find that cellphone network expansion reduced insurgent violence at both the district level and within specific tower coverage areas. Our conclusions have to remain somewhat cautious regarding the distinction between the human and the signals intelligence, since direct tests are impossible. However, we see that the reduction of violence applies at both the district and the local level. Also, the effect seems to be particularly strong in Sunni areas. Had the signals-intelligence mechanism been solely responsible for the decrease in violence, we should have seen an effect at the district but not the local level, and there should not have been any differences between sectarian areas since it was possible to implement signals intelligence gathering across all of them. These results suggest (with some uncertainty of course) that cellphone coverage reduces insurgent violence largely because it enhances voluntary information flow from noncombatants to counterinsurgents by reducing the risks of informing. We expect similar results to hold wherever government security services (and their allies) have a robust ability to act on the increase in human and signals intelligence that expanded cellular coverage provides.

These results speak to a number of literatures. First, they contribute to a growing body of literature demonstrating the beneficial effects of expanding communications opportunities. ${ }^{58}$ Our findings suggest cellular communications may confer a range of governance and stability advantages that have not previously been tested in this literature. Second, they highlight the importance of civilian decisions that fall far below the threshold of actually participating in the conflict and are not subject to collective action problems. That such decisions can be critical suggests political science theories may have greatly overestimated what it takes to dramatically change the dynamics of conflicts.

Third, the results also speak to debates about what kinds of ethnic concentrations increase the risk of civil war, ${ }^{59}$ and to discussions of why insurgencies are more successful when operating from rural areas. ${ }^{60}$ The question at issue in these debates is whether urban terrain makes it easier or harder for state security forces to control violent groups. The key argument on the "easier" side is that in urban areas many people necessarily have information on the insurgents, by virtue of simple population

58. See Jensen 2011; and Aker 2010.

59. Weidmann 2009.

60. See Kocher 2004; Bates 2008; and Staniland 2010. 
density, which makes them acutely vulnerable to informants. By showing that exogenous environmental changes that reduce the cost of informing leads to a clear and unambiguous reduction in insurgent violence, we provide solid empirical grounding for a mechanism discussed, but never tested, in this literature.

Fourth, and perhaps most importantly, these results are highly relevant to ongoing policy in all countries facing active insurgencies and the need to grow their wireless infrastructure. For countries such as Colombia, India, Pakistan, and Thailand, the policy debates typically hinge on how tightly regulated access to phones and SIM cards should be. For the international community the debates are about the extent to which the expansion of cellular communications should be subsidized. In Afghanistan, for example, there was an extended discussion about whether or not foreign governments and aid agencies should work with telecommunications firms that made compromises with local militants to protect their towers and staff, with some arguing there should be little engagement so long as towers were being turned off at night when the Taliban demanded. Our analysis suggests that in addition to their economic impact, cellular coverage can carry counterinsurgency benefits, at least in a context with highly capable government forces. In such places, local governments and the international community may well want to subsidize the expansion of cellphone networks regardless of how the firms managing them interact with the locals.

\section{Supplementary Material}

Replication data and an online appendix are available at http://dx.doi.org/10.1017/ S0020818313000489.

\section{References}

Aker, Jenny C. 2010. Information from Markets Near and Far: Mobile Phones and Agricultural Markets in Niger. American Economic Journal: Applied Economics 2 (3):46-59.

Andreas, Peter. 2002. Transnational Crime and Economic Globalization. In Transnational Organized Crime and International Security. Business as Usual? edited by Mats R. Berdal and Monica Serrano, 37-52. Boulder, CO: Lynne Rienner.

Arquilla, John, David Ronfeldt, and Michele Zanini. 1999. Networks, Netwar, and Information-Age Terrorism. In Strategic Appraisal: The Changing Role of Information in Warfare, edited by Zalmay Khalilzad and John P. White, 75-112. Santa Monica, CA: RAND Corporation.

Bahney, Benjamin, Howard J. Shatz, Carroll Ganier, Renny McPherson, and Barbara Sude. 2011. An Economic Analysis of the Financial Records of al-Qa'ida in Iraq. Santa Monica, CA: RAND Corporation.

Bates, Robert H. 2008. When Things Fell Apart: State Failure in Late-Century Africa. New York: Cambridge University Press.

Bellows, John, and Edward Miguel. 2009. War and Local Collective Action in Sierra Leone. Journal of Public Economics 93 (11-12):1144-57 
Berman, Eli, Michael Callen, Joseph H. Felter, and Jacob N. Shapiro. 2011. Do Working Men Rebel? Insurgency and Unemployment in Iraq and the Philippines. Journal of Conflict Resolution 55 (4): 496-528.

Berman, Eli, Joseph H. Felter, Jacob N. Shapiro, and Erin Troland. 2013. Modest, Secure, and Informed: Successful Development in Conflict Zones. NBER Working Paper 18674. Cambridge, MA: National Bureau of Economic Research.

Berman, Eli, Jacob N. Shapiro, and Joseph H. Felter. 2011. Can Hearts and Minds Be Bought? The Economics of Counterinsurgency in Iraq. Journal of Political Economy 119 (4):766-819.

Biddle, Stephen, Jeffrey A. Friedman, and Jacob N. Shapiro. 2012. Testing the Surge: Why Did Violence Decline in Iraq in 2007? International Security 37 (1):7-40.

Condra, Luke N., and Jacob N. Shapiro. 2012. Who Takes the Blame? The Strategic Effects of Collateral Damage. American Journal of Political Science 56 (1):167-87.

Cordesman, Anthony. 2005. Iraq's Evolving Insurgency. Washington, DC: Center for Strategic and International Studies.

Diamond, Larry. 2010. Liberation Technology. Journal of Democracy 21 (3):69-83.

Garrett, R. Kelly, and Paul N. Edwards. 2007. Revolutionary Secrets: Technology's Role in the South African Anti-Apartheid Movement. Social Science Computer Review 25 (1):13-26.

Innes, Martin. 2006. Policing Uncertainty: Countering Terror Through Community Intelligence and Democratic Policing. Annals of the American Academy of Political and Social Science 605 (1):222-41.

Jensen, Robert. 2011. The Digital Provide: Information (Technology), Market Performance, and Welfare in the South Indian Fisheries Sector. Quarterly Journal of Economics 122 (3):879-924.

Kalyvas, Stathis N. 2006. The Logic of Violence in Civil War. New York: Cambridge University Press.

Kocher, Matthew. 2004. Human Ecology and Civil War. University of Chicago. Unpublished manuscript, University of Chicago, Chicago.

Leahy, Kevin. 2005. The Impact of Technology on the Command, Control, and Organizational Structure of Insurgent Groups. Master's thesis, US Army Command and General Staff College, Fort Leavenworth, KS.

Lindsay, Carrie Lee. 2011. Iraq Order of Battle-District Level. Dataset. Stanford, CA: Stanford University.

Lyall, Jason. 2010. Are Coethnics More Effective Counterinsurgents? Evidence from the Second Chechen War. American Political Science Review 104 (1):1-20.

Muckian, Martin. 2006. Structural Vulnerabilities of Networked Insurgencies: Adapting to the New Adversary. Parameters 36 (Winter):14-25.

Nunn, Nathan, and Leonard Wantchekon. 2011. The Slave Trade and the Origins of Mistrust in Africa. American Economic Review 101 (7):3221-52.

Oak Ridge National Laboratory. 2008. LandScan Global Population Database. Oak Ridge, TN. Available at <http://www.ornl.gov/landscan/>. Accessed 14 June 2011.

Pierskalla, Jan H., and Florian M. Hollenbach. 2013. Technology and Collective Action: The Effect of Cell Phone Coverage on Political Violence in Africa. American Political Science Review 107 (22):207-24.

Shirky, Clay. 2011. The Political Power of Social Media. Foreign Affairs 90 (1):28-41.

Staniland, Paul. 2010. Cities on Fire: Social Mobilization, State Policy, and Urban Insurgency. Comparative Political Studies 43 (12):1623-49.

Strother, Tiffany. 2007. Cell Phone Use by Insurgents in Iraq. Shawnee, OK: Urban Warfare Analysis Center.

Sundberg, Ralph, and Erik Melander. 2013. Introducing the UCDP Georeferenced Event Dataset. Journal of Peace Research 50 (4):523-32.

US Department of Defense (DOD). 2008. Measuring Stability and Security in Iraq: March 2008 Report to Congress in Accordance with the Department of Defense Appropriations Act 2008. Washington, DC: Government Printing Office.

US Government Accountability Office (GAO). 2007. The Department of Defense's Use of Solatia and Condolence Payments in Iraq and Afghanistan. Washington, DC: Government Printing Office. 
Vanden Eynde, Oliver. 2011. Targets of Violence: Evidence from India's Naxalite Conflict. Unpublished manuscript, Paris School of Economics, Paris.

Weidmann, Nils B. 2009. Geography as Motivation and Opportunity: Group Concentration and Ethnic Conflict. Journal of Conflict Resolution 53 (4):526-43.

World Food Programme (WFP). 2004. Baseline Food Security Analysis in Iraq. UN World Food Programme, Iraq Country Office.

2 2006. Food Security and Vulnerability Analysis in Iraq. UN World Food Programme, Iraq Country Office.

2008. Comprehensive Food Security and Vulnerability Analysis (CFSVA). UN World Food Programme, Iraq Country Office. 